\title{
Gottfried von Strassburg - A German Humanist of the Twelfth Century Par Excellence
}

\author{
Albrecht Classen \\ University of Arizona \\ aclassen@u.arizona.edu \\ https://dx.doi.org/10.12795/futhark.2012.i07.04
}

Abstract: Normally we identify the so-called Renaissance of the twelfth centuty with theologians, philosophers, and artists. But many poets from the turn of the century (1200) have made major intellectual contributions to this Renaissance as well. Especially Gottfried von Strassburg's Tristan can be regarded as an extraordinary literary accomplishment characterized by its fascinating combination of fictional elements with those of a philosophical origin. The purpose of this article is to recognize the central message of Tristan as not being limited to the theme of love, but, emerging from the discourse of love, as a critical engagement with basic question pertaining to human existence.

Keywords: Renaissance of the Twelfth Century, Gottfried von Strassburg, Tristan, love discourse, medieval philosophy and theology

When Charles Homer Haskins coined the phrase 'Renaissance of the twelfth century', he had put his finger on a monumental intellectual-cultural movement that certainly deserves such a glamorous epithet, even though we have learned to differentiate considerably this optimistic evaluation of that period since then ${ }^{1}$. Major cathedrals, castles, and other monuments were erected during that Gothic period, which we do not need to define too narrowly as limited precisely to the years between 1100 and 1200 . Universities sprang up all over Europe, and the secular courts also developed extensively, providing a new forum for the arts, literature, and music, not to mention the growth of cities, international trade, and the sciences ${ }^{2}$. This was also the time we usually identify with the

\footnotetext{
${ }^{1}$ Charles Homer Haskins, The Renaissance of the Twelfth Century (Cambridge: Harvard University Press, 1927). Instead of providing a long list of related studies that have appeared since, I like to refer to the recent book by Fiona J. Griffiths, The Garden of Delights: Reform and Renaissance for Women in the Twelfth Century. The Middle Ages Series (Philadelphia: University of Pennsylvania Press, 2007), who offers an excellent complementary perspective focusing on the extraordinary contributions by an abbess, Herrad of Hohenbourg.

${ }^{2}$ See, for instance, Thomas Woods, How the Catholic Church uild Western Civilization (Washington, D.C.: Regenery, 2005); Robert L. Benson, Giles Constable and Carol D. Lanham, eds., Renaissance and Renewal in the Twelfth Century (Oxford: Clarendon
} 
flowering of knighthood, tournaments, courtly love, and the corresponding poetry and musical compositions. Likewise, artists created most beautiful sculptures, frescoes, altar pieces, jewelry, and other works, leaving behind a dazzling array of enormous creativity and skill that confirm the true 'renaissance' of that period. 'Renaissance' here means both the revival of classical learning and the arts (mostly Roman, but also Greek, particularly with the rediscovery of many hitherto seemingly lost texts by Aristotle), and also the development of new modes of expression, innovative themes and ideals, values and concepts.

One of the most exciting topics from that time that continues to intrigue us today was the (re)discovery of courtly love, the unfathomable but most powerful erotic relationship between man and woman in the secular, courtly context. The Catholic Church had certainly always espoused the idea of love (agapé) in a religious meaning, and Latin writers long before the twelfth century had regularly referred to love in their narratives and poems, but it then had normally carried a philosophical value and usually applied to the sophisticated ethical relationship between men bonded by friendship (not homosexual in nature) ${ }^{3}$. In the twelfth century, by contrast, the courtly lady entered the picture, and this rapidly developed into a whole cultural concept of a complex system of amatory relationships, normally outside of the bonds of marriage. This was expressed perhaps most learnedly, yet also deeply ironically, by the Paris based cleric Andreas Capellanus in his highly influential treatise (largely a collection of dialogues) De amore (Latin, ca. 1180-1190). But it has remained a matter of profound debate whether he truly advocated love between non-married people, as he emphasizes in the first two books, formulating repeatedly the basic laws of love, idealizing the value of adultery as a fundamental expression of courtly culture, or whether he spoke tongue-in-cheek and really intended to fight against love outside of the bonds of marriage as prescribed by God (third book). At any rate, De amore proved to be an ideal forum for the public and learned debate about the true nature of love and its

Press, 1982); Tina Stiefel, The Intellectual Revolution in Twelfth-Century Europe (London: Croom Helm, 1985).

${ }^{3}$ C. Stephen Jaeger, The Envy of Angels: Cathedral Schools and Social Ideals in Medieval Europe, 950-1200. The Middle Ages Series (Philadelphia: The University of Pennsylvania Press, 1994).

Futhark 7 (2012)

Classen, Gottfried von Strassburg, 115-130

ISSN $1886-9300$ 
basic precepts, and in its highly dialectic and contradictory nature this treatise might indeed best represent the Renaissance of the twelfth century ${ }^{4}$.

Vernacular poets were the first to develop this most intriguing and soon enough popular topic of courtly love, as richly documented by the huge corpus of courtly love lyrics and romances especially since the second half of the twelfth century. However, whereas courtly love poetry virtually never talks about marriage, courtly romances deviate from this considerably. Moreover, some writers, such as the Anglo-Norman Marie de France (fl. ca. 1160-1200), strongly argued in favor of love-based marriage. In other words, the topic of love had become a hotly debated issue, characteristic of twelfth-century culture, proving to be a matter of highly learned and artistic exchanges. However, Arthurian romance mostly pursued a different agenda, if we ignore the Lancelot-Guinevere tryst, focusing on individual ethics (Chrétien's Erec and Yvain) and also religious ideals pertaining to the grail (Wolfram von Eschenbach, Parzival).

One of the best German poets who powerfully contributed to the intriguing discourse on courtly love was Gottfried von Strassburg (fl. 1190-1220), about whom we know surprisingly little, yet about whom we can say much in terms of his education, learning, values, ideals, intentions, and ethics. He composed a number of excellent love poems ("Minnelieder," or songs of love), contained in the famous Manesse songbook, created in Zürich very early in the fourteenth century on behalf of the urban-patrician family Manesse. This manuscript contains the songs of 137 famous German courtly love poets, and each of them is also presented by an imaginary portrait. On folio $364 \mathrm{r}$ we see Gottfried von Strassburg, seated among a group of apparently like-minded people, he clothed in a dark blue gown and holding a diptych, a typical attribute of the learned scholar, and in allegorical depictions the symbol of rhetoric. While he holds up his left hand in a gesture probably to underscore an argument, the audience around him, all of them lively gesturing, seems to be deeply involved in this debate, probably about the true meaning of the poet's

\footnotetext{
${ }^{4}$ See, for instance, Paolo Cherchi, Andreas and the Ambiguity of Courtly Love. Toronto Italian Studies (Toronto and Buffalo: University of Toronto Press, 1994); Don Alfred Monson, Andreas Capellanus, Scholasticism, and the Courtly Tradition (Washington, D.C.: Catholic University of America, 2005).

Futhark 7 (2012)

Classen, Gottfried von Strassburg, 115-130
}

ISSN 1886-9300 
teachings regarding love. The fact that a king is seated to Gottfried's right (our left), and that a queen (?) is standing to his left (our right) signals how much the poet obviously enjoyed public renown and could appeal to the members of the highest level of courtly society ${ }^{5}$.

Moreover, iconographically the artist modeled the image of the poet closely after traditional Pentecost illustrations, hence attributed Gottfried almost the power of divine inspiration, as if his Tristan would have to be read as a parallel to the account in the New Testament. In fact, as some scholars have argued, there are some messianic elements underlying the presentation of the male protagonist, Tristan, who seems to be not only a prodigal son in terms of his stupendous learning and education, but who also excels in knighthood, politics, and, above all, love, putting everyone at court, including his own uncle, King Mark, to shame for their inadequacies in practically every respect ${ }^{6}$.

Unfortunately, as is very common for medieval authors, there are, as far as we can tell today, no historical documents that would inform us about Gottfried. So we are entirely dependent on the statements contained in his works, comprising, apart from the lyric poems, his own, probably most famous, version of the Tristan and Isolde romance composed around $1205^{7}$. Undoubtedly, this romance attracted the greatest attention in the German Middle Ages, as documented by the survival of eleven complete and eighteen fragmentary manuscripts containing the text. Today, in a time of the modern book market that often produces at times millions of copies of a best seller, this seems minuscule, but for the Middle Ages any

${ }^{5}$ Codex Manesse: Die Miniaturen der Großen Heidelberger Liederhandschrift.
Herausgegeben und erläutert von Ingo F. Walther unter Mitarbeit von Gisela Siebert
(Frankfurt a. M.: Insel, 1988), plate 121, p. 246-47.
${ }^{6}$ C. Stephen Jaeger, Ennobling Love: In Search of a Lost Sensibility. The Middle Ages
Series (Philadelphia: The University of Pennsylvania Press, 1999); see also Dietmar
Mieth, Dichtung, Glaube und Moral: Studien zur Begründung einer narrativen Ethik mit
einer Interpretation zum Tristanroman Gottfrieds von Straßburg. Mainzer theologische
Studien, 7 (Mainz: Matthias Grünewald-Verlag, 1976).
7 There are numerous excellent English translations available, but I will offer my own
here for precision's sake; for the historical-critical edition from which I will cite, see
Gottfried von Strassburg, Tristan, ed. Karl Marold. Unchanged 5th reprint of the $3^{\text {rd }}$
edition, together with an apparatus improved on the basis of Friedrich Ranke's
collations, prepared and with an expanded epilogue by Werner Schröder (Berlin and
New York: de Gruyter, 2004).

Futhark 7 (2012)

Classen, Gottfried von Strassburg, 115-130

ISSN $1886-9300$ 
work that has come down to us in more than a handful of manuscripts can be regarded as a great success, particularly if we consider the exponentially much higher number of listeners who enjoyed his romance over at least two centuries.

Of course, there were even more popular works, such as Wolfram von Eschenbach's Parzival and his Willehalm, both preserved in approximately eighty manuscripts, and absolute 'hits' such as the Roman de la rose, first composed by Guillaume de Lorris (ca. 1230) and then vastly expanded and completed by Jean de Meun (ca. 1260-1270), with ca. 300 manuscripts. Nevertheless, Gottfried was generally regarded with great respect, and we can be certain that audiences far and wide, at least in the south and west of German, were most anxious to get hold of a copy of his Tristan or to hear it performed by a minstrel. The manuscripts that we have today date from the thirteenth to the fifteenth century. Moreover, since Gottfried left his romance as a fragment, two subsequent poets, Ulrich von Türheim (ca. 1230) and Heinrich von Freiberg (ca. 1290), set themselves to the task to write a closure to the text, each developing his own version, obviously an expression both of great respect for the original author and of their deep frustration with a romance that takes the audience to a most problematic dilemma for the protagonist at the end without providing a satisfactory, even if tragic, conclusion ${ }^{8}$.

Although Gottfried of Strassburg remains such an elusive figure for us in historical terms, his Tristan proves to be a treasure trove to explore the true meaning of the term 'Renaissance of the twelfth century.' As Gottfried's posterity has consistently confirmed, this was one of the most appealing, profound, and fascinating versions of the international Tristan narratives, or motif. In his Alexander, Rudolf von Ems (flourishing ca. 1230-1250) effusively praises Gottfried as a master of his art who knew exceedingly well how to write about courtly love and to compose a most sophisticated romance in highly delicate language. He also confirmed that this model poet had composed didactic love poetry, next to his Tristan. For Rudolf, Gottfried was a "wîse" (wise) man who went through

\footnotetext{
${ }^{8}$ William C. McDonald, The Tristan Story in German Literature of the Late Middle Ages and Early Renaissance. Studies in German Language and Literature, 5 (Lewiston, Queenston, and Lampeter: The Edwin Mellen Press, 1990).
}

Futhark 7 (2012)

Classen, Gottfried von Strassburg, 115-130

ISSN 1886-9300 
extensive learning and excelled by profound knowledge, which also applied to his deep understanding of the true nature of love. Several decades later, Konrad von Würzburg expressed his deep admiration of Gottfried (in his verse narrative Herzmäre). In his Wilhelm von Österreich (1314) Johann von Würzburg identified Gottfried as extraordinarily skilled in erotic rhetoric.

So, altogether there is no doubt that Gottfried represented one of the key figures in high-medieval German literature, as confirmed both by his contemporaries and by modern scholarship at least since the twentieth century (in the nineteenth century, philologists harbored a more negative view of his work because of the morally debatable idealization of the adulterous love affair between Tristan and Isolde). In terms of his education, value system, and identification with courtly culture he fully belonged to the 'Renaissance' of the long twelfth century.

We know that Gottfried's patron was a man called Dietrich, as testified by the acrostic spread throughout the text (just like Gottfried's name and those of the two protagonists). Although we cannot be certain about Dietrich's identity, it is clear that Tristan enjoyed a significant function as a representative art work for the Strassburg aristocracy, similarly to previous Tristan versions some of which were created on behalf of the first English Angevin dynasty. Gottfried's close association with Strassburg does not make him to a burgher or merchant, an unlikely notion, whereas our best bet seems to be that he was a well-trained, university educated (Paris or Bologna?) cleric in the service of an urban ministerialis, or highranking aristocratic administrator. However, throughout the romance the concept of the merchant as an important mask and strategy for Tristan plays an important role, signaling that Gottfried also intended to appeal to the elite urban population.

In many ways we can identify Gottfried as an outstanding representative of the intellectual movement of the twelfth-century Renaissance, considering his complex and profound reflections upon and references to the liberal arts, philosophy, and also religious notions prevalent at his time. Nevertheless, and this makes his Tristan to such a unique masterpiece, Gottfried explicitly developed 
innovative ideals about human interaction, communication, love, ethics, and the pursuit of individual happiness ${ }^{9}$.

The prologue to his romance contains one of the most amazing medieval concepts of a social utopia which the text later realizes in the famous love-cave scene, though the lovers cannot stay for ever and need to return to the court, or human society, once King Mark has granted them his permission, falsely believing that his suspicion about their adulterous love affair was wrong ${ }^{10}$.

For Gottfried, his romance really served as a literary platform to outline the dominant ideals that he embraced himself and presented to his audience, where the individual would strive for public esteem and honor. He emphasizes these points most explicitly because many other people at his time had failed, as he argues, to realize those values and yet pretend to be courtly and educated. In fact, Gottfried challenges them as hypocrites who do not know how to tread the narrow path of virtue (v. 37) and are not strong enough anyway to accept the cumbersome and difficult challenges to achieve that goal. The poet distinguishes most remarkably between the ordinary people and those with an "edele[ ] herz[ ]" (v. 47), or a noble heart. He identifies a small community of those who have accomplished the task of accepting these values fully, and Gottfried counts himself among them for whom he has composed his romance: "den herzen den ich herze trage" (v. 48; for those with a heart I have heartfelt feelings). The others only pursue worldly pleasures and are not willing to accept cumbersome sorrow and suffering, though these are intimate elements essential for the full realization of honorable life. In fact, the poet strongly advocates a dialectical notion of a world determined by love and sorrow, happiness and pain. Gottfried almost speaks like a preacher, certainly borrowing from Scripture here, outlining in great intensity the fundamental values of the most esoteric, perhaps almost divine, notion of love, which is even superseding traditional notions of courtly love:

\footnotetext{
${ }^{9}$ Albrecht Classen, Verzweiflung und Hoffnung: Die Suche nach der kommunikativen Gemeinschaft in der deutschen Literatur des Mittelalters. Beihefte zur Mediaevistik, 1 (Frankfurt a. M., Berlin, et al.: Peter Lang, 2002), 279-358.

${ }_{10}$ Tomas Tomasek, Die Utopie im "Tristan" Gotfrieds von Straßburg. Hermaea, Neue Folge, 49 (Tübingen: Niemeyer, 1985).

Futhark 7 (2012)

Classen, Gottfried von Strassburg, 115-130
}

ISSN 1886-9300 


\begin{abstract}
ein ander werlt die meine ich, diu sament in eime herzen treit ir süeze sûr, ir liebez leit, ir herzeliep, ir senede nôt, ir liebez leben, ir leiden tôt, ir lieben tôt, ir leidez leben. dem lebene sî mîn leben ergeben, der werlt wil ich gewerldet wesen, mit ir verderben oder genesen.

I have another world in mind, a world which carries in one heart its sweet sorrow, its loving suffering, its heartfelt love, its longing pain, its loving life, its suffering death, its loving death, its suffering life. To that life may my own life be dedicated, in that world I want to live as its citizen, perish with it or regain my health.
\end{abstract}

No other medieval poet had formulated the dialectical nature of true love more powerfully, enigmatically, and more emphatically than Gottfried, who obviously knew exceedingly well how to utilize the wide gamut of rhetorical strategies that he must have learned during his university studies (unless he attended a cathedral school). Intriguingly, the subsequent image of the text as bread carries strong echoes of the Eucharist as a medium for memory as discussed by contemporary theologians, such as Lothar dei Conti and Rupert of Deut $^{11}$. But the poet goes one step further and also claims that he himself had been so fortunate enough to experience this ardent and heart-rending love himself because, as he states unequivocally in this prologue, he wants to dedicated his entire life to this world where that kind of love is possible.

His personal experiences provided him, as he underscores, guidance and direction for the composition of this romance (v. 6770). Later, when commenting on the mysterious love cave into which

\footnotetext{
${ }^{11}$ Mark Chinca, Gottfried von Strassburg: Tristan. Landmarks of World Literature (Cambridge: Cambridge University Press, 1997), 55-57.

Futhark 7 (2012)

Classen, Gottfried von Strassburg, 115-130
}

ISSN $1886-9300$ 
the two lovers retire, hiding from King Mark's jealousy and wrath once he has confirmed his suspicions about their affair, the authornarrator returns to the issue of his personal involvement and knowledge about the love enjoyed by Tristan and Isolde. In the love cave the two protagonist have no need for food or drink, and just enjoy each other's company, which seems to baffle the audience of Gottfried's text. But he opposes his critics and emphasizes: "es dunket mich genuoch hier an" (16919; it seems to me to be sufficient). Moreover, he himself indicates that he has enjoyed that kind of esoteric, amatory nourishment: "ich treip ouch eteswenne / alsus getâne lebesite" (16924-25; occasionally I also pursue such a life style).

Subsequently Gottfried describes the cave in great detail, strongly suggesting that he had a Gothic cathedral in mind, despite the roundness of the space in the cave, which could easily represent the choir. Both shape and colors carry a strong symbolic meaning, and the narrator elaborates a complete set of ethical ideals written into the stone, very much like the facade of a twelfth-century church, an impressive literary realization of the philosophical and ethical discourse current at that time. All these minutiae, however, serve only one purpose, to reflect upon the true meaning of love: "diu minne sol ouch kristallîn / durchsihtic und durchlûter sîn" (16987-88; love also ought to be like a crystal, transparent and translucent).

The elaborate description of the numerous details constituting the love cave and their allegorical interpretation have provided much evidence for Gottfried scholarship to determine the extensive theological and philosophical education that the author had received. Although he followed to some extent the model provided by Thomas de Bretagne with his Tristan version (ca. 1170-1180), Gottfried went much deeper and developed significant ethical and moral correlations between, on the one hand, colors objects, shapes, and forms, and love, virtue, and even faith on the other. In this approach he closely followed traditional twelfth-century exegetical literature, taking his audience from the historical (literal) to the typological (allegorical), moral, and finally, maybe, even to the anagogical level, transforming Tristan's and Isolde's love into an 
example of spiritual love ${ }^{12}$. This blending of a secular and a religious reading of love represents the triumph of the twelfth-century discourse on courtly love, adding a divine dimension to the physical experience of love, only matched, if not superseded, not much later by Dante in his Divina Commedia. Parallel to Gottfried, and probably also in sharp competition with him, Wolfram von Eschenbach argued in his Parzival (ca. 1205) for the transformation of secular knighthood into a religious community crowned by the Holy Grail on castle Munsalvaesche.

Gottfried clearly meant this cave as a utopia, and as in the case of all utopias, eventually the two lovers leave again, actually quite relieved because they also need social contact, community, and the court, best captured by the term "êre" (17702; honor). Nevertheless, the lovers never regain the same degree of happiness there and can no longer recapture the previous sense of intimacy and happiness as in the love cave because the public exerts too much pressure on them, watching and observing them carefully. King Mark even goes so far as to ask them to avoid gazing at each other too passionately and not to pass too much time together in private, indirectly admitting that he secretly knows about their love relationship and desires to preserve the pretense for himself and the public that this is a deception (vv. 17716-25).

Significantly, Gottfried describes the love cave as a most remote place which only those can find who have dedicated themselves to the true labor of love (vv. 17095-103). Those fortunate ones will be regaled with absolute happiness for the heart, with infinite joy for the eyes and the ears, and they would never want to abandon that locale again (17099-103). The narrator then makes the important effort to authenticate this incredible utopia by confirming it through his eye witness account: "Diz weiz ich wol, wan ich was dâ" (v. 17104; I know this well because I was there). He describes meticulously his various efforts to reach that goal, which was right in view of his eyes. In fact, as he emphasizes, he had danced near-by many times, he had enjoyed the sight, inside and outside, and the light that shines through the allegorical windows-they are typologically significant because the three windows evoke the image

${ }^{12}$ Christoph Huber, Gottfried von Straßburg "Tristan und Isolde": Eine Einführung. $2^{\text {nd }}$ ed. (2000; Berlin: Schmidt, 2001), 104-08.

Futhark 7 (2012) Classen, Gottfried von Strassburg, 115-130

ISSN $1886-9300$ 
of the holy trinity-had illuminated his heart many times. As he further explains, he had known of the cave since his eleventh year, although he himself had never been to the country of Kurnewâle (vv. 17139-42).

Gottfried underscores, in other words, the symbolic and the realistic meaning of the cave at the same time, and so invites his readers/listeners to embrace the notion of utopian love represented by Tristan's and Isolde's experience.

With this in mind we can return to the ponderous prologue where the poet appeals to a unique kind of audience who shares the ideals and values undergirding this kind of love, transforming them all into members of the community with the noble heart. Love creates the spiritual power to turn ordinary people into true nobles who understand, and emphasize with, the sorrow and happiness of lovers, and in turn are infused with the same ethical values as these two literary figures. Those with a noble heart know the meaning of true love and understand and support lovers, irrespective of all the pain and sorrow that will certainly ensue (vv. 106-22). In fact, that pain actually ennobles the lovers and takes them to new heights of human existence.

Gottfried was not the first to write about the Tristan motif, but he claims to have found the best version available as a source and to have rendered that one into his own romance. Referring to the many previous poets ("Ich weiz wol, ir ist vil gewesen," v. 131; I know well that there have been many), he situates himself in the context of a broader literary discourse, assuming, however, to be the leading voice among them all. Refusing to listen to the many different voices debating what the true story of Tristan might have been, Gottfried insists on Thomas of Bretagne as being the master creator. He himself had heard of him one and then had begun a search for his text in the vernacular (Old French) and in Latin (v. 159). The simple reference to one book that he had finally found and read serves as a great illustration of the new bookish culture that determined twelfthcentury culture with its growing libraries and intensive book production all over Europe (vv. 164-65).

Once he had discovered the 'true' account of the two lovers, Gottfried created his own version and submitted it to the community

Futhark 7 (2012)

Classen, Gottfried von Strassburg, 115-130

ISSN 1886-9300 
of noble hearts (vv. 169-71). He clearly asserts that the reading of his romance would strongly contribute to the growth and strengthening of each individual member of that community: "ez liebet liebe und edelet muot" (v. 174; it loves love and ennobles the mind).

Summarizing the essence of this love story, Gottfried also presents the fundamental virtues that undergird all courtly culture as determining factors of the Renaissance of the twelfth century: "liebe, triuwe, stæter muot, / êre und ander manic guot" (vv. 180-81; love, loyalty, constant mind, honor, and many other virtues). Moreover, formulating a powerful message about courtly love as talked about and perhaps also practiced by twelfth-century nobility, the narrator underscores: "liebe ist ein alsô sælic dinc, / ein alsô sæleclîch gerinc, / daz nieman âne ir lêre / noch tugende hât noch êre" (vv. 187-90; love is such a glorious thing, such an inspiring matter that [as I claim] no one has virtues or honor without its guidance).

The necessary downside, however, is also mentioned, insofar as no one can hope to expect to gain happiness from love, and by the same token honor and public praise who has not also experienced sorrow resulting from love (vv. 204-210) ${ }^{13}$.

Undoubtedly, these are most potent statements about the fundamental value system of courtly society, and we can be certain that Gottfried ardently espoused them himself and appealed to his audience to follow this model. By the same token, he also presented literary characters who, though they ultimately fail to pursue their amatory dream to its ultimate goal, represent the ideal in courtly education and culture. It would be erroneous to identify Gottfried with his fictional figure Tristan, but he invests him with a whole set of abilities and skills that clearly serve as the model for courtly society at large.

Whereas Tristan's father Riwalin certainly impresses us with his courtliness and chivalry, there are also serious character flaws in him that finally make him fail and die, leaving behind his son as an orphan because his mother also passes away out of grief over the loss of her husband. Ignoring essential details of the narrative for

${ }^{13}$ Mark Chinca, History, Fiction, Verisimilitude: Studies in the Poetics of Gottfried's
Tristan. Texts and Dissertations, 35 (London: Modern Humanities Research
Association for The Institute of Germanic Studies, University of London, 1993).
Futhark 7 (2012) Classen, Gottfried von Strassburg, 115-130

ISSN $1886-9300$ 
brevity's sake, we need to pay close attention to Tristan's education which represents an ideal for a twelfth-century prince-almost like in the wide-spread genre of mirrors for princes-which Gottfried certainly embraced for himself as far as he could reasonably claim in his position as a learned cleric, or master, as the illustrator in the Manesse manuscript identified him later.

From a very early age Tristan begins to study, reading books of unspecified nature, but certainly belonging to the canon of reading material supporting the study of the artes liberales (liberal arts). Moreover, he is also practicing rhetoric, musical performance with voice and instruments. But he also does not ignore the basics of chivalry, such as riding a horse, all kinds of athletics, wielding the wide range of knightly weapons, hunting, and also courtly games ("hovespil," 2119). With the age of fourteen he is called back home from his teachers and then charged with exploring the entire country as thoroughly as possible, preparing himself thereby for the kingship that he is supposed to assume if he can overcome the opponent, Morgan, though he will never assume that role for a number of reasons that ultimately drive him away from his country to his uncle, King Mark, and from there to Ireland where he will meet his beloved, princess Isolde.

The young man, while still under the tutelage of his fosterfather Rual li Foitenant, one day boards a ship of Norwegian merchants to buy some birds of prey. These sailors soon realize his extraordinary skill and beauty, and kidnap him. This is possible because his attention is caught by a chessboard and he is invited to join a game of chess, thus distracting him from the events surrounding him, while the Norwegians silently lift the anchor and take off with their prisoner. Not only does he impress everyone on the ship with his playing skills, but also with his ability to speak about individual moves on the chessboard in foreign tongues (2287), not to mention the various songs that he performs during the breaks. Later, once he has been freed and ultimately has arrived at King Mark's court, he continues to dazzle his social environment. He demonstrates to the royal huntsmen how to cut up a dead deer and how to transform the carcass into an art object. At the court he displays extraordinary musical abilities, knowing how to play every 
instrument to perfection, even those instruments no one in Cornwall has ever heard of.

By the same token, Gottfried does not isolate his protagonist from the traditional context of courtly love and secular education, emphasizing that Tristan knew about "lachen, tanzen, singen, / rîten, loufen, springen, / zuhten unde schallen, / daz kunde er mit in allen" (vv. 3495-97; to laugh, to dance, to sing, to ride horses, to run, to jump, to behave courtly and to display happiness; everything that he could do together with them all). Although he pretends to know little of the musical arts, in reality he is more than a master of all styles, melodies, and instruments. In fact, Tristan proves to be the best musician of them all, evoking endless enthusiasm among his audience, a clear reflection of the great emphasis placed on music in theoretical and practical terms during the twelfth century as part of the study of the quadrivium at the university (music, astronomy, arithmetic, and geometry).This also implies that Gottfried had studied, as the foundation, the trivium (grammar, rhetoric, and dialectic), as indicated by his solid knowledge of classical literature, his elegant style, and the persuasiveness of his arguments, and then the quadrivium ${ }^{14}$.

Finally, Tristan perfectly commands every language spoken at Mark's court, responding to all the courtiers in their native tongues as if he were the new Messiah, overcoming the fundamental problem of people to speak to each other after the destruction of the Tower of Babel. Not surprisingly, everyone in the crowd admires the young man like a new god: "â Tristan, wære ich alse duo!" (v. 3708; 'ah, Tristan, if I were only like you!). Ironically, however, as much as all these skills make him to the idol of the court, and also help him survive even most dangerous situations later in his life, particularly winning princess Isolde as a bride for his uncle Mark, they also evoke jealousy and envy soon enough which has him actually fear for his life.

Tristan's urbanity and learning, his chivalry and physical attraction, his intelligence and political skills all make him to a model character of the world of the twelfth century, almost to a Renaissance man in the high Middle Ages. When Tristan is knighted by Mark, the

\footnotetext{
${ }^{14}$ Mark Chinca, Gottfried von Strassburg, 7-8.

Futhark 7 (2012)

Classen, Gottfried von Strassburg, 115-130
}

ISSN 1886-9300 
narrator offers an allegorical reading of his clothing specifically capturing the essence of a true courtly person, shining forth through his "hôhe[n] muot" (v. 4565; high spirit), "vollez guot" (v. 4566; wealth), "bescheidenheit" (v. 4567; understanding), and "hövescher $\sin$ " (v. 4569; sense of courtliness) ${ }^{15}$.

This also finds expression in Gottfried's famous literary excursus where he discusses for the first time in medieval vernacular literature the canon of most significant Middle High German poets who had lived prior, or were still contemporary, to him: Hartmann von Aue, Wolfram von Eschenbach (?), Bligger von Steinach, Heinrich von Veldeke, Reinmar von Hagenau, and Walther von der Vogelweide (vv. 4555-5011). Here and throughout the romance we also observe Gottfried's extensive but creative borrowing from classical literature (e.g., Ovid and Virgil), and his indebtedness to major twelfth-century philosophers, such as Alanus ab Insulis with his Anticlaudianus (ca. 1180) ${ }^{16}$.

Despite the total lack of historical evidence relating to Gottfried's biography, his Tristan emerges as an excellent literary mirror of a most learned, rhetorically sophisticated Middle High German poet who was an outstanding representative of the twelfthcentury Renaissance, deeply steeped in secular and theological learning, strongly relying on biblical typology for his erotic romance. He knew exceedingly well how to combine in a unique manner literary entertainment with philosophical, ethical, moral, and scientific teaching, providing an extraordinarily challenging ideal of the community of those with a noble heart, a community that would

\footnotetext{
${ }^{15} \mathrm{C}$. Stephen Jaeger, The Origins of Courtliness: Civilizing Trends and the Formation of Courtly Ideals 939-1210. The Middle Ages Series (Philadelphia: University of Pennsylvania Press, 1985), 40-42, 102-10; 220-24. See also Malcolm Vale, The Princely Court: Medieval Courts and Culture in North-West Europe (Oxford and New York: Oxford University Press, 2001), 165-200; see also Maurice Keen, Chivalry (New Haven and London: Yale University Press, 1984).

${ }^{16}$ Christoph Huber, Die Aufnahme und Verarbeitung des Alanaus ab Insulis in mittelhochdeutschen Dichtungen: Untersuchungen zu Thomasin von Zerklaere, Gottfried von Straßburg, Frauenlob, Heinrich von Neustadt, Heinrich von St. Gallen, Heinrich von Mügeln und Johannes von Tepl. Münchener Texte und Untersuchungen zur deutschen Literatur des Mittelalters, 89 (Munich: Artemis, 1988). See also C. Stephen Jaeger, Medieval Humanism in Gottfried von Strassburg's Tristan und Isolde. Germanische Bibliothek. Reihe 3: Untersuchungen und Einzeldarstellungen (Heidelberg: Winter, 1977).
}

Futhark 7 (2012)

Classen, Gottfried von Strassburg, 115-130

ISSN $1886-9300$ 
understand and appreciate the dialectics of love as presented by Tristan and Isolde ${ }^{17}$.

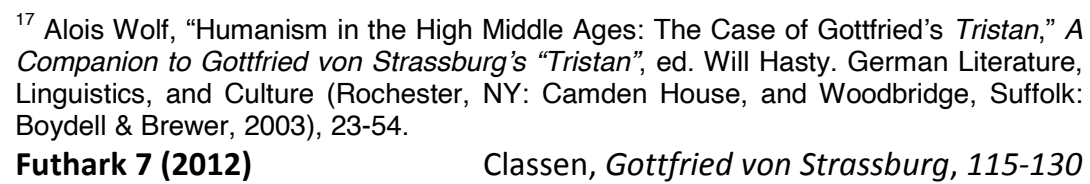

ISSN 1886-9300 